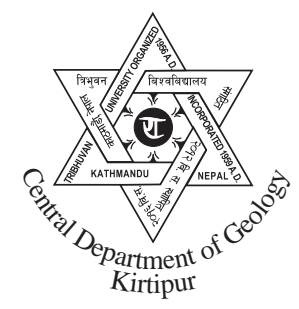

\title{
Status of sand mining and quality in northern Kathmandu, Central Nepal
}

\author{
*Mamata Sayami and Naresh Kazi Tamrakar \\ Central Department of Geology, Tribhuvan University, Kirtipur, Kathmandu, Nepal
}

\begin{abstract}
Growing trend of urbanization in Kathmandu has increased the demands of sand for building materials of concrete. Demand of sand has been fulfilled from terrace and riverbed mining in northern region of Kathmandu and by importing from west of Kathmandu. Riverbed excavation and some quarries in terrace deposits are illegally operated. Although riverbed excavation is prohibited, majority of the sand comes from such mining. Questionnaire analysis, analysis of secondary data and sand samples were carried out in laboratory to obtain (a) the existing status of sand mining and (b) the quality of sand supplied to the market. About $60 \%$ demand of sands have been fulfilled through riverbeds while $40 \%$ have been fulfilled through terrace deposits. The Sanla and the Manahara Rivers have been the most efficiently excavated rivers. About $1865 \mathrm{~m}^{3}$ sands from river and $1238 \mathrm{~m}^{3}$ from terraces have been excavated per day. Future demand of sand may increase considering $60 \%$ increase of household in the valley. Out of total excavation sites in the valley, $40 \%$ illegal sites are located in rivers and 5\% in terrace deposits. Mining policy and laws are weak to control illegal mining and to bring miners and dwellers into the framework of taxation. The river or terrace sands do not differ much in major constituents, but the former sands are more matured. Both sands are hazardous in terms of mica content that approaches 10 to $32 \%$ lying beyond the acceptable limit of $8 \%$. Other deleterious materials are quite low in percentage and do not exceed 3\%. If processing can be applied to reduce mica content at a commercial-scale, the sands in the Kathmandu Valley will be probably of good quality.
\end{abstract}

\section{INTRODUCTION}

Rapid urbanization for last two decades in the Kathmandu Valley (Fig. 1) has increased excessive demands of sand for construction purpose. During the past, sands were mostly supplied from riverbeds located in the northern regions of the valley. After the prohibition of riverbed mining from Nepal Government in 1991 (Kharel et al. 1992), terrace mining in the same northern regions began. However, the illegal mining has still been operated in river areas. Most of the sand supplied to the market has come from riverbeds.

Mainly the rivers originated from the Shivapuri Range in the north of the Kathmandu Valley (Fig. 2); the Mahadev, Sanla, Bishnumati, Dhobi, Bagmati and the Manahara Rivers are the sources of sand.

*Corresponding author:

E-mail address: mamtasayami@gmail.com
Gneiss and granite (Stöcklin and Bhattrai 1982) of the Shivapuri Range weathered to produce large amount of sand transported remarkably during monsoon season. Other sources of sand are the fluviodeltaic deposits of the Tokha, Gokarna and Thimi Formations (Yoshida and Igarashi 1986; DMG 2001) which are incised by the rivers exposing the scarps. Excavation of riverbed sand has invited various environmental problems in river. Unsystematic mining has caused erosion and instability of the riverbanks, and pollution of rivers (Tamrakar 2004; Adhikari and Tamrakar 2005; Bajracharya 2006). Several workers studied on sand of the Kathmandu Valley with different aspects (Kharel et al. 1992; Sadaula 1993; Paudel et al. 1995; Kharel et al. 2002). Yet the mining history, production, supply channel, market potential, and comparison of sand quality have not been well focused in earlier studies. Therefore, this paper attempts to treat in these aspects. 


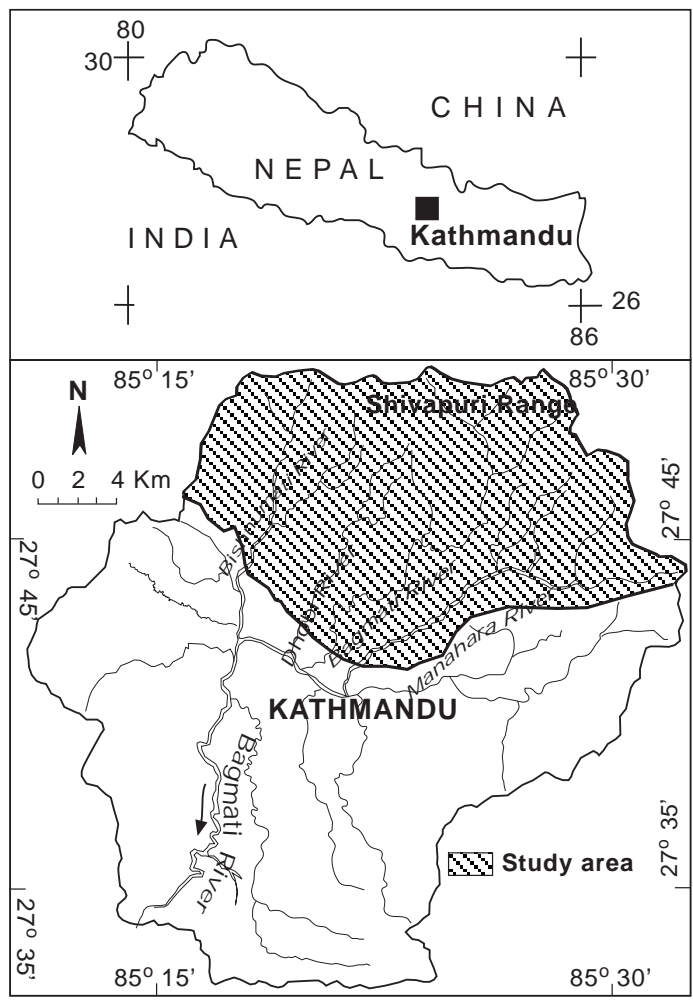

Fig. 1 Location map of study area

\section{MINING BACKGROUND}

Rapid urbanization within a short span in the Kathmandu Valley for last two decades has increased the demand of sand. Construction of infrastructures has grown day by day, adding the demand of sand. In the earlier around 1980, the demand of sand was fulfilled from riverbed of large rivers in the northern regions of the valley. In 1991, the Bagmati Bridge that links Kathmandu with Lalitpur collapsed due to haphazard exploitation of sand from the riverbeds. Similarly, the destruction of bridge at Sankhamul Ghat and exposure of foundation of different bridges in the valley were also caused by riverbed mining. Since 1991, the Nepal Government has prohibited riverbed mining and started delivering license to mine sand from terrace deposits. Therefore, most of the huge sand mining sites have been located in terrace deposits. Nevertheless, the riverbed mining has been undergoing illegally these days.

\section{DEMAND AND SUPPLY OF SAND}

The households in the Kathmandu Valley are growing haphazardly without any proper planning.
The households increased by $48 \%$ during the last two decades (based on CBS 2001). Migration of people from the rural areas, centralization towards the capital and conflict in country seem to be causes for increase in population and houses in Kathmandu. The total population growth and houses in Bishnumati Watershed alone have grown more than $40 \%$ according to the data of 1991 and 2001. This figure could have been increased after 2001 by $60 \%$. According to the survey and personal communication with Village Development Committee, the excessive growth of infrastructure has demanded about 3100 $\mathrm{m}^{3}$ of sand per day in the Kathmandu Valley. At present these demands have been fulfilled from terraces and riverbeds of the valley and river sands imported from the adjacent regions (western) of the Kathmandu Valley.

Recently, some of the major terraces have been excavated from Rahultar, Jaraku, Paniyatar, Manamaiju, Baluwapati, Baniyatar, Adhikarigau, Aryalgau, Gothatar and Mulpani. About $40 \%$ of the market demand have been fulfilled from terrace sand and $60 \%$ from the riverbed sand. About $35 \%$ of the terrace mining are registered (based on Questionnaire analysis). Figure 3 shows the volume of sand mined from river and terrace in each river section. Figure 4 shows the present and extinct mining sites. The supply from the Sanla River covers the largest volume (748 $\mathrm{m}^{3}$ per day) of the riverbed sand in the Kathmandu Valley. Among the terraces, those of the Mahadev River (Rawaltar, Jaraku, Paniyatar and Manamaiju) cover the largest volume of sand (440 $\mathrm{m}^{3}$ per day) excavated. The riverbed sand excavation is also remarkable in the Manahara River $\left(630 \mathrm{~m}^{3}\right.$ per day). The riverbed sand production from the Dhobi River is the least ( $36 \mathrm{~m}^{3}$ per day). The total riverbed sand accounts for $1865 \mathrm{~m}^{3} /$ day, terrace sand accounts for $1238 \mathrm{~m}^{3} / \mathrm{day}$, and the total sand that have been extracted in the valley each day approaches $3103 \mathrm{~m}^{3}$.

\section{LAWS AND POLICY OF EXCAVATION}

Since fiscal year 1977/78, sand deposits have been leased, licensed and exploited under the supervision of the District Development Committee. The following norms were regulated for the exploitation of sand.

1. Five meters must be left at both banks of a river while exploiting sand from river and the depth of 


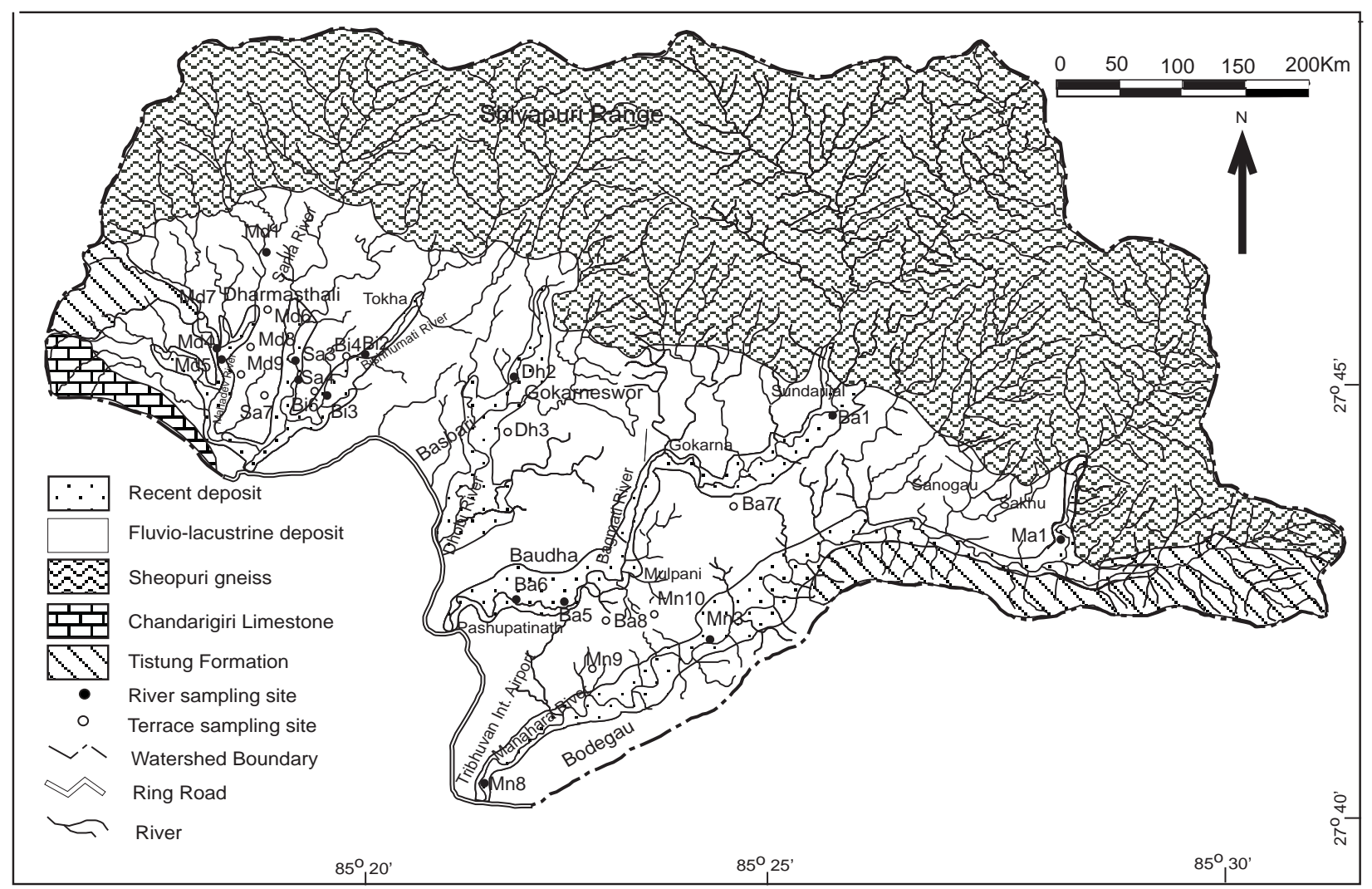

Fig. 2 A map indicating sampling sites of sand

excavation should not exceed more than $1 \mathrm{~m}$ from the riverbed.

2. No excavation should be made within the radius of 200 metres from any infrastructure.

3. Authorized permit must be submitted from the concerned persons or agencies if they use road to the mining sites.

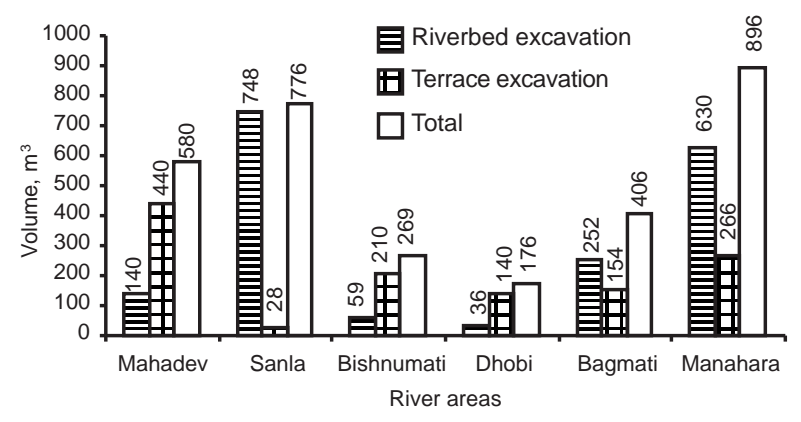

Fig. 3 Volume of sand mined from river and terrace in each river section
4. Leaseholders must submit progress and product quantity to the concerned institution.

5. Product of the quarry must give priority of local demand.

6. The concerned authority must give information regarding leased and licensed area to the Department of Mines and Geology within 35 days of issued date.

Regardless of permits and licensing the quarry area, the rest of the statements are not clear and neither there are policies concerning environmental protection, public health, proper taxation and penalty for the illegal mining.

\section{MINING METHODS}

Although sand mining has increased rapidly, the technique of mining has not been improved with a time. In most of the sites, still traditional techniques have been used and illegal mining has been common. 


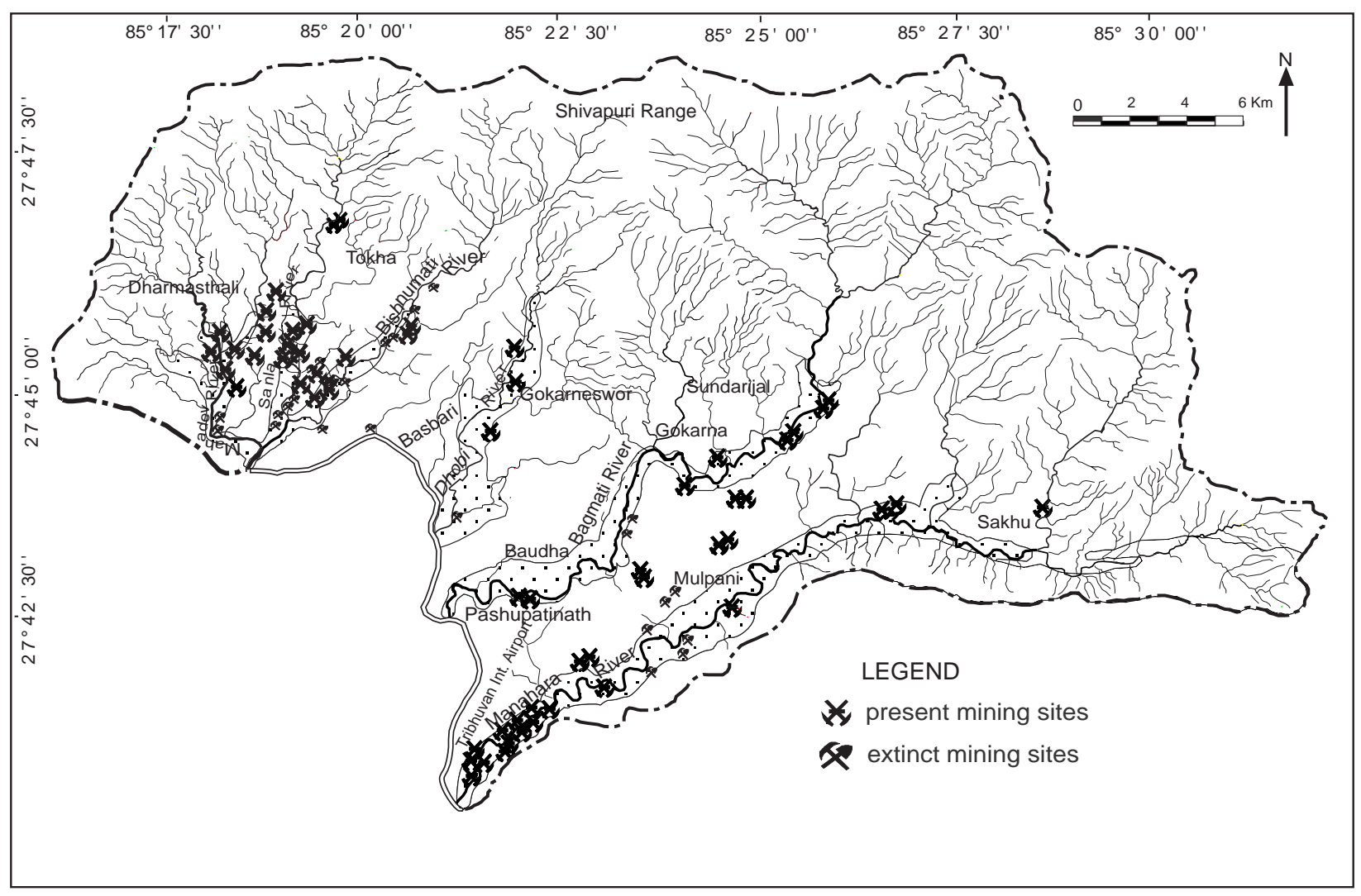

Fig. 4 A map showing present and extinct mining sites

\section{Illegal river mining}

After 1991 Nepal Government banned river mining. Nevertheless several river excavation sites have been located in the major rivers of the valley. Commonly, miners used excavators to dig a channel (Fig. 5a) in pre-monsoon season, so that sand could be collected in the ditches during monsoon (June-September). Along the channel, bamboo net was built in several rows to retard discharge of sand downstream. Besides that, channel was diverted for trapping sand in the ditch and was also diverted to collect water in flood plain to wash sand. During post-monsoon, different sieves were used directly in the channel to separate gravel and sand. Generally, the domestic tools like shovel, twangro, bamboo bucket, sieves and water pumps were used in the riverbed mining. In the flood plains of the Sanla and the Manahara Rivers, the riverbeds were dug upto 8 meters from their original surface levels. Water pumps were installed to draw water collected during excavation.

\section{Illegal small-scale terrace mining}

Terrace mining was extensive during pre-monsoon season. Except in certain permitted sites, traditional methods were used for excavating sand illegally by small teams of landowners and contractors. In this process, miners excavated sand from the base of the terrace using shovels (Fig. 5b). After mining, scraps were left in the same place without proper leveling of the ground. Such illegal and local mining produces cheaper sand compared to the sophisticated mining because its cost of production is low.

\section{Legal and advance mining}

Most of the large-scale mining from terraces were legal and were more sophisticated than the traditional method. In sites like terraces along the Mahadev River and the Manahara River, hydraulic back-hoe excavators and dump trucks were used to remove overburden and excavate sand (Fig. 5c). Benching and stripping methods were used to excavate sand from terraces. Plastic pipes of about $0.2 \mathrm{~m}$ diameter were used to load sand from the site to the dump 


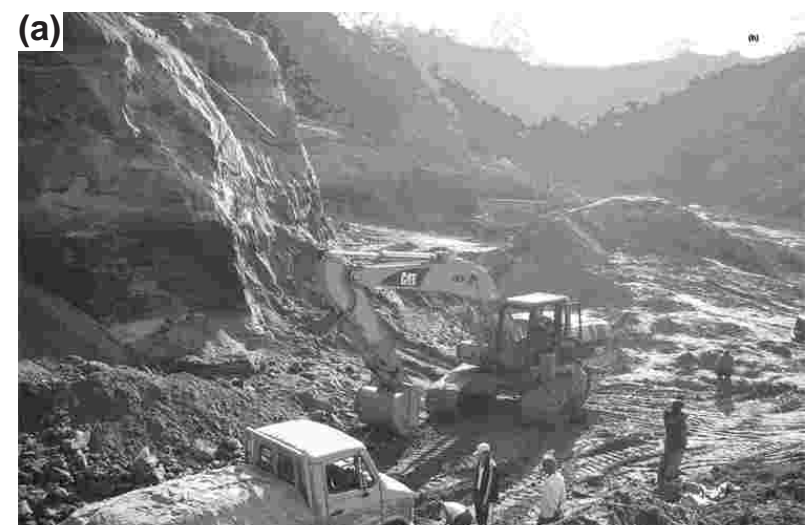

(b)
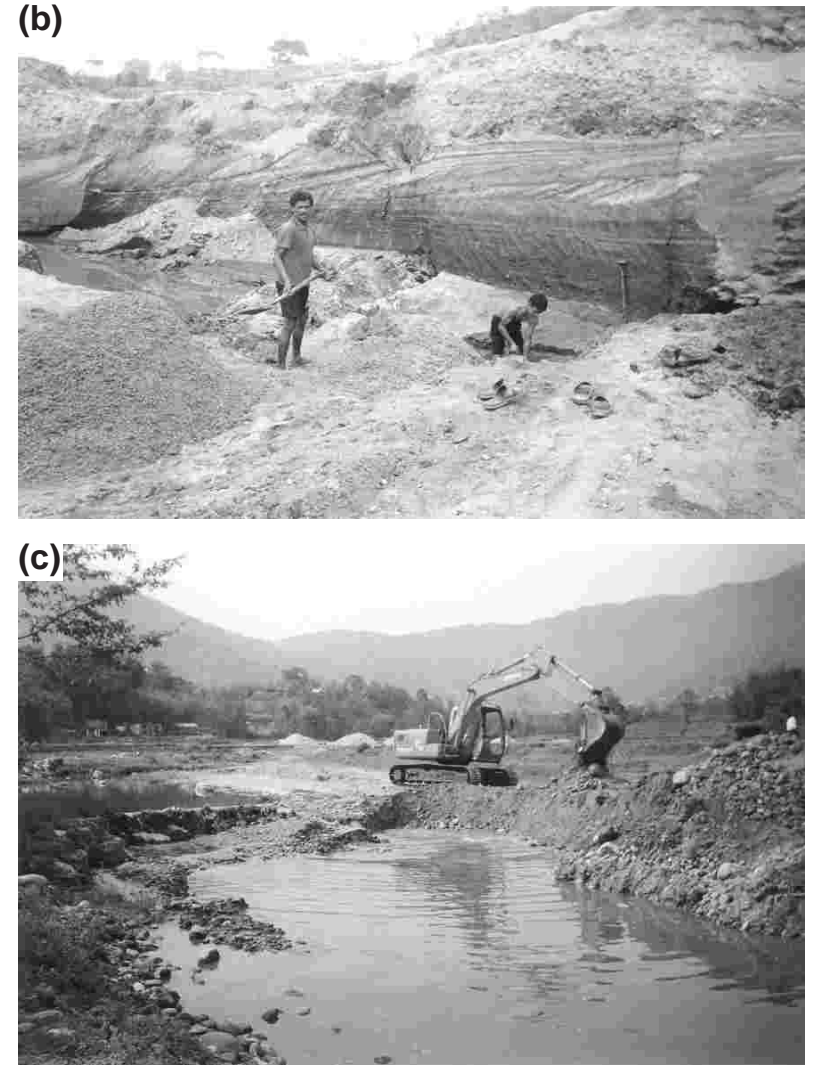

Fig. 5 Photographs: (a) Excavator digging a channel in pre monsoon season, (b) excavation of sand from the base of the terrace in the Sanla Khola and (c) hydraulic back-hoe excavator and dump truck are used to remove overburden and excavate sand

trucks. Contractors directly supplied sands to the market or to the consumers or to the processing companies where further washing and screening of gravel and clay would occur. The scraps are used for filling the ground and are also supplied to the market. The cost of sand thus excavated is higher compared to the unprocessed sand.

\section{QUALITY OF SAND}

Based on the mining sites, the sampling sites along the rivers and terraces (Fig. 2) were selected for sampling and laboratory analyses. The samples were obtained during monsoon season by quartering method.

\section{Texture of sand}

The samples were sieved for grain size and sorting using the American Standard of Testing Material (ASTM) sieves. Quartz grains from the medium sizegrade of sand were observed for roundness. The results are indicated in Table 1. Median size $\left(\mathrm{d}_{50}\right)$ of the river sand ranged from 0.65 (Sanla River) to 1.44 $\mathrm{mm}$ (Bagmati River). The median sizes of the terrace sands ranged from 0.84 (Dhobi River area) to 1.31 $\mathrm{mm}$ (Manahara River area). The river sands were moderately sorted ( 0.89 ; Sanla River) to poorly sorted (1.59 ; Bishnumati River). The terrace sands were poorly sorted and ranged from 1.20 (Mahadev River area) to 1.46 (Dhobi River area). The sands of river and terrace did not show distinct difference in size and sorting. Considering the river sands, the grain size was coarser towards the upstream segments. Sands from both river and terrace were coarse-grained.

Quartz grains of the river sands ranged from angular (1.93; Sanla River) to subangular (2.50; Bishnumati River), and those of the terrace sands ranged from angular (1.70; Bishnumati River area) to subangular (2.18; Manahara River area) based on Folk's roundness-scale. Comparing the both sands, terrace sands were found to be more angular (1.85) than the river sands (2.18).

Percent fines in the river sands ranged from 0.19 (Sanla River) to $1.24 \%$ (Bishnumati River), whereas the same in the terrace sands ranged from 0.21 (Dhobi River area) to $1.08 \%$ (Bagmati River area). The range of percent fines seems to be slightly larger in the river sands compared to the terrace sands. However, this range is still less than $5 \%$ and sands are texturally immature.

\section{Composition of sand}

\section{Major composition}

The medium sand-size grade of each sample was grain mounted and was point counted under the binocular microscope. About two hundred grains per 
Table 1: Texture, composition, and physico-chemical properties of sands

\begin{tabular}{|c|c|c|c|c|c|c|c|c|c|c|c|c|c|c|c|c|c|c|}
\hline \multirow[b]{2}{*}{ Sample } & \multirow[b]{2}{*}{$\begin{array}{l}\text { Sample } \\
\text { no. }\end{array}$} & \multicolumn{3}{|c|}{ Texture } & \multicolumn{6}{|c|}{ Framework constituents } & \multirow[b]{2}{*}{ MMI } & \multicolumn{3}{|c|}{ Recalculated $\%$} & \multirow[b]{2}{*}{$\%$ Fines } & \multirow[b]{2}{*}{ s $\mathrm{O}$} & \multirow[b]{2}{*}{$\mathrm{C}$} & \multirow[b]{2}{*}{$\begin{array}{l}\text { Density } \\
\mathrm{kg} / \mathrm{m}^{3}\end{array}$} \\
\hline & & $\begin{array}{l}\mathrm{d}_{50} \\
\mathrm{~mm}\end{array}$ & I & & $\overline{\mathrm{Q}}$ & $\mathrm{F}$ & $\mathrm{L}$ & $\mathrm{M}$ & $\mathrm{H}$ & $\mathrm{U}$ & & Q & $\mathrm{F}$ & $\mathrm{L}$ & & & & \\
\hline \multicolumn{19}{|l|}{ (a) Rivers } \\
\hline \multirow[t]{3}{*}{ Mahadev River } & Md1R & 0.80 & 1.4 & 1.9 & 65 & 16 & 5 & 11 & 3 & 0 & 305 & 75 & 19 & 6 & 0.35 & & 0.2 & 2525 \\
\hline & $\mathrm{Md} 4 \mathrm{R}$ & 0.80 & 1.4 & 2.0 & 61 & 13 & 9 & 15 & 1 & 1 & 274 & 73 & 16 & 10 & 0.43 & & 0.1 & 2325 \\
\hline & Md5R & 0.85 & 1.4 & 1.9 & 62 & 7 & 8 & 19 & 3 & 1 & 416 & 81 & 9 & 10 & 0.15 & 0.33 & 0.0 & 2352 \\
\hline \multirow{2}{*}{ Sanla River } & $\mathrm{Sa} 3 \mathrm{R}$ & 0.87 & 1.0 & 1.9 & 59 & 11 & 6 & 20 & 3 & 1 & 346 & 78 & 15 & 8 & 0.16 & & 0.1 & 2666 \\
\hline & Sa3R & 0.43 & 0.8 & 1.9 & 49 & 14 & 4 & 32 & 1 & 0 & 278 & 74 & 21 & 6 & 0.22 & 0.26 & 0.1 & 2581 \\
\hline \multirow[t]{2}{*}{ Bishnumati River } & Bi2R & 0.90 & 1.6 & 2.5 & 63 & 8 & 7 & 16 & 5 & 0 & 406 & 80 & 10 & 9 & 1.06 & & 0.0 & 2602 \\
\hline & Bi3R & 0.78 & 1.6 & 2.5 & 67 & 7 & 9 & 14 & 1 & 1 & 418 & 81 & 9 & 11 & 1.42 & 0.35 & 0.1 & 2343 \\
\hline Dhobi River & $\mathrm{Dh} 2 \mathrm{R}$ & 0.73 & 1.3 & 2.1 & 61 & 7 & 8 & 21 & 3 & 0 & 417 & 81 & 9 & 10 & 0.68 & 0.36 & 0.2 & 2637 \\
\hline \multirow[t]{3}{*}{ Bagmati River } & Ba1R & 2.14 & 1.2 & 2.0 & 62 & 4 & 13 & 17 & 3 & 1 & 367 & 79 & 5 & 17 & 0.16 & & 0.4 & 2383 \\
\hline & Ba5R & 0.93 & 1.3 & 2.2 & 66 & 17 & 4 & 11 & 1 & 0 & 318 & 76 & 19 & 5 & 0.22 & & 0.1 & 2696 \\
\hline & Ba6R & 1.23 & 1.7 & 2.1 & 67 & 8 & 4 & 19 & 1 & 0 & 527 & 84 & 10 & 6 & 0.6 & 0.38 & 0.1 & 2629 \\
\hline \multirow[t]{3}{*}{ Manahara River } & Ma1R & 1.41 & 1.6 & 2.0 & 53 & 9 & 8 & 26 & 3 & 1 & 326 & 77 & 12 & 11 & 0.24 & & 0.2 & 2611 \\
\hline & Ma3R & 0.87 & 1.1 & 2.3 & 62 & 10 & 7 & 18 & 2 & 0 & 361 & 78 & 13 & 9 & 0.41 & & 0.2 & 2664 \\
\hline & Ma6R & 0.45 & 1.1 & 2.1 & 64 & 12 & 6 & 17 & 1 & 0 & 358 & 78 & 15 & 7 & 0.38 & 0.3 & 0.1 & 2516 \\
\hline \multicolumn{19}{|l|}{ (b) Terrace } \\
\hline \multirow{8}{*}{$\begin{array}{l}\text { Mahadev River } \\
\text { area }\end{array}$} & Md6(a)T & 0.93 & 1.5 & 2.1 & 52 & 14 & 11 & 23 & 0 & 0 & 210 & 68 & 19 & 14 & 1.31 & & 0.8 & 2404 \\
\hline & Md6(b)T & 0.76 & 1.5 & 2.1 & 57 & 12 & 13 & 18 & 0 & 1 & 234 & 70 & 14 & 16 & 0.85 & & & 2279 \\
\hline & Md6(c)T & 0.76 & 1.7 & 1.5 & 58 & 8 & 15 & 19 & 0 & 1 & 260 & 72 & 9 & 18 & 0.5 & & & 2319 \\
\hline & $\operatorname{Md} 7(a) T$ & 2.00 & 1.0 & 1.8 & 55 & 17 & 8 & 20 & 0 & 0 & 216 & 68 & 21 & 10 & 0.81 & & 0.5 & 2437 \\
\hline & $\operatorname{Md} 7(b) T$ & 0.71 & 1.2 & 1.6 & 58 & 13 & 13 & 16 & 0 & 0 & 219 & 69 & 15 & 16 & 0.24 & & & 2555 \\
\hline & $\operatorname{Md} 8(a) T$ & 0.34 & 1.3 & 1.8 & 54 & 18 & 12 & 16 & 0 & 0 & 180 & 64 & 21 & 15 & 3.26 & & & 3017 \\
\hline & $\operatorname{Md} 8(b) \mathrm{T}$ & 0.99 & 0.6 & 1.8 & 53 & 15 & 11 & 20 & 0 & 0 & 202 & 67 & 19 & 14 & 0.65 & & & 2927 \\
\hline & Md9T & 0.71 & 0.8 & 2.1 & 58 & 12 & 18 & 10 & 0 & 1 & 189 & 65 & 14 & 21 & 0.8 & 0.21 & 0.2 & 2618 \\
\hline Sanla River area & $\mathrm{Sa} 5 \mathrm{~T}$ & 0.93 & 1.3 & 1.8 & 62 & 7 & 11 & 19 & 0 & 0 & 329 & 77 & 9 & 14 & 0.48 & 0.18 & 0.1 & 2691 \\
\hline \multirow{5}{*}{$\begin{array}{l}\text { Bishnumati River } \\
\text { area }\end{array}$} & $\mathrm{Bi} 4(\mathrm{a}) \mathrm{T}$ & 0.84 & 1.3 & 1.8 & 57 & 15 & 10 & 18 & 0 & 0 & 235 & 70 & 18 & 12 & 1.21 & & 0.1 & 2418 \\
\hline & Bi4(b)T & 1.23 & 1.2 & 1.7 & 56 & 17 & 7 & 21 & 0 & 0 & 237 & 70 & 21 & 9 & 0.69 & & 0.1 & 2589 \\
\hline & $\operatorname{Bi5}(\mathrm{a}) \mathrm{T}$ & 0.87 & 1.7 & 1.6 & 53 & 15 & 8 & 24 & 0 & 0 & 228 & 70 & 20 & 11 & 0.63 & 0.23 & 0.1 & 2696 \\
\hline & $\mathrm{Bi5}(\mathrm{b}) \mathrm{T}$ & 1.27 & 1.1 & 1.7 & 56 & 22 & 9 & 12 & 0 & 0 & 181 & 64 & 26 & 10 & 0.63 & & 0.1 & 2561 \\
\hline & $\mathrm{Bi} 6 \mathrm{~T}$ & 0.71 & 1.5 & 1.7 & 56 & 16 & 8 & 19 & 0 & 0 & 228 & 70 & 20 & 10 & 1.13 & & 0.2 & 2369 \\
\hline \multirow{5}{*}{$\begin{array}{l}\text { Dhobi River } \\
\text { Bagmati River } \\
\text { area }\end{array}$} & Dh3T & 0.84 & 1.5 & 1.8 & 60 & 11 & 16 & 13 & 0 & 0 & 230 & 70 & 12 & 18 & 0.21 & 0.25 & 0.5 & 2411 \\
\hline & $\mathrm{Ba} 7(\mathrm{a}) \mathrm{T}$ & 0.93 & 1.4 & 1.8 & 58 & 19 & 2 & 20 & 0 & 0 & 271 & 73 & 24 & 3 & 1.24 & & 0.3 & 2383 \\
\hline & $\mathrm{Ba} 7(\mathrm{~b}) \mathrm{T}$ & 1.32 & 1.1 & 1.8 & 56 & 23 & 4 & 17 & 0 & 0 & 213 & 68 & 27 & 5 & 1.77 & & & 2744 \\
\hline & $\mathrm{Ba} 7(\mathrm{c}) \mathrm{T}$ & 0.81 & 1.0 & 1.7 & 62 & 11 & 11 & 16 & 0 & 0 & 284 & 74 & 13 & 13 & 0.79 & & & 1234 \\
\hline & Ba8T & 0.76 & 1.1 & 2.1 & 59 & 17 & 5 & 18 & 0 & 1 & 269 & 73 & 20 & 7 & 0.5 & 0.24 & 0.4 & 2544 \\
\hline Manahara River & Ma9T & 1.74 & 1.4 & 2.1 & 62 & 16 & 6 & 15 & 0 & 1 & 278 & 74 & 19 & 8 & 0.53 & & 0.0 & 2302 \\
\hline area & Ma10T & 0.89 & 1.2 & 2.3 & 65 & 12 & 2 & 21 & 0 & 0 & 462 & 82 & 15 & 3 & 0.38 & 0.22 & 0.1 & 2618 \\
\hline
\end{tabular}

mount were counted. The results are indicated in Table 1 . Sands were mainly composed of quartz, feldspar, rock fragments and mica. QFL modes of the river and the terrace sands are shown in Fig. 6. The overall QFL composition of the river sands was $\mathrm{Q}_{78}, \mathrm{~F}_{13}$ and $\mathrm{L}_{9}$ (Fig 6). Quartz ranged from 53 to $67 \%$, while feldspar ranged from 7 to $17 \%$. Rock fragments ranged from 4 to $13 \%$. Rock fragments were aggregates of quartz and feldspar, quartz and mica, feldspar and mica and quartz, feldspar and mica. Among the micas muscovite exceeded biotite. The mica ranged from 11 to $32 \%$, the highest amount being obtained from the Sanla River. Heavy minerals like tourmaline and garnet were present in few amounts and ranged from 1.93 to 3.14.
The overall QFL composition of the terrace sands was $\mathrm{Q}_{70}, \mathrm{~F}_{18}$ and $\mathrm{L}_{12}$ (Fig 6) Terrace sands were dominantly composed of quartz grains that ranged from 52 to $65 \%$. Feldspar ranged from 7 (Sanla River area) to $22 \%$ (Bishnumati River area). Rock fragments ranged from 2 to $18 \%$. Micas varied from 10 to $24 \%$. Muscovite dominated biotite. Heavy minerals were generally rare in terrace sands.

Mineralogical maturity index, a ratio of quartz to feldspar plus rock fragment, ranged from 274 (Mahadev River) to 527 (Bagmati River) in the river sands and from 180 (Mahadev River area) to 462 (Manahara River area) in the terrace sands. The presence of lower amount of feldspar and rock fragment compared to quartz suggested that both 


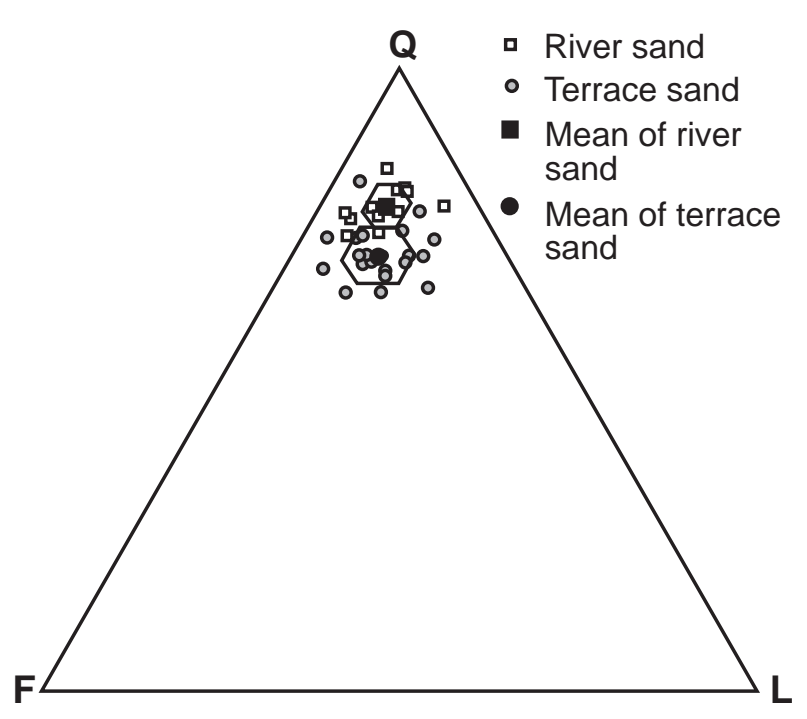

Fig. 6 QFL triangular diagram showing composition of sands from riverbeds and terraces; polygons represent one standard deviation from the mean

river and terrace sands were mineralogically matured except few samples from the terraces. The river sands were more matured compared to the terrace sands.

\section{Deleterious material}

The common material that present on the sand that lowers the quality, economic value and weakens the infrastructure is known as deleterious material. The variation of deleterious materials is shown in Fig. 7.

Percent mica: Average mica ranged from 11 to $32 \%$ (Sanla River) in the river sands. Mica ranged from 10 (Mahadev River area) to 24\% (Bishnumati River area) in the terrace sands. In average, river sands contained $19 \%$ and terrace sands contained $18 \%$ mica. Presence of high amount of mica in sand affects strength and bonding with cement (Fookes and Revie 1982) and brings problems known to occur with surface finishes related to 'shelling out' (particle popping out). High mica content tends to absorb water in the mixture of sand and cement. Nextly, increased proportion of cement paste is required to be workable with high amount of flaky mica. British Standard Institution (BSI) recommends avoiding sand with more than $8 \%$ mica (BSI 1973).

Percent fines: The average fines in the river sands and terrace sands were 0.52 to 0.69 , respectively.
Fines in sands provide grain coating and prevent bonding with cement and increase demand of water. However, the fines were quite low in the sands sampled.

Percent organic material: Organic material ranged from 0.26 to $0.38 \%$ in the river sands and 0.18 to $0.25 \%$ in the terrace sands. These ranges lied within the acceptable limit of less than $1 \%$. Organic material in river sands $(0.33 \%)$ slightly exceeded that of the terrace sand $(0.22 \%)$. Pollution of river probably increased organic material in the river sands.

\section{Bulk density of sand}

The bulk density of the river sand ranged from 2400 (Mahadev River) to $2637 \mathrm{~kg} / \mathrm{m}^{3}$ (Dhobi River) and that of the terrace sands ranged from 2226 (Dhobi River area) to $2690 \mathrm{~kg} / \mathrm{m}^{3}$ (Sanla River area) (Table 1). Both river and terrace sands have appreciable densities, which fall on medium density and these sands are good enough for use.

\section{Durability against acid}

The sand used for construction must be durable against acid. When sands were treated in dilute $\mathrm{HCl}$ for 24 hours and the loss of weight were calculated the percent loss (which was assumed to be equal to the percent calcium carbonate) was 0.04 to $0.20 \%$ in the river sands and that was 0.06 to $0.49 \%$ in the terrace sands. Therefore, the amount of soluble mineral against the dilute acid was very low.

\section{COMPARISON OF QUALITY}

Texturally, there was no huge difference in sands of the river and the terrace sampled. However, the terrace sands were slightly coarser compared to the river sands. Feldspar and rock fragments were slightly higher in the terrace sands compared to the river sands. Both terrace and river sands had very high amount of mica content, which made these sands poor in order to be used as construction material. Heavy minerals were absent in the terrace sands. Amount of fines was somewhat higher in the terrace sands probably due to contamination by the clay layer. However, the existing range lied within the acceptable limit $(<1 \%)$. The organic content was higher in the river sands than in the terrace sands. The terrace sands were less durable against dilute $\mathrm{HCl}$ compared to the river sands. 

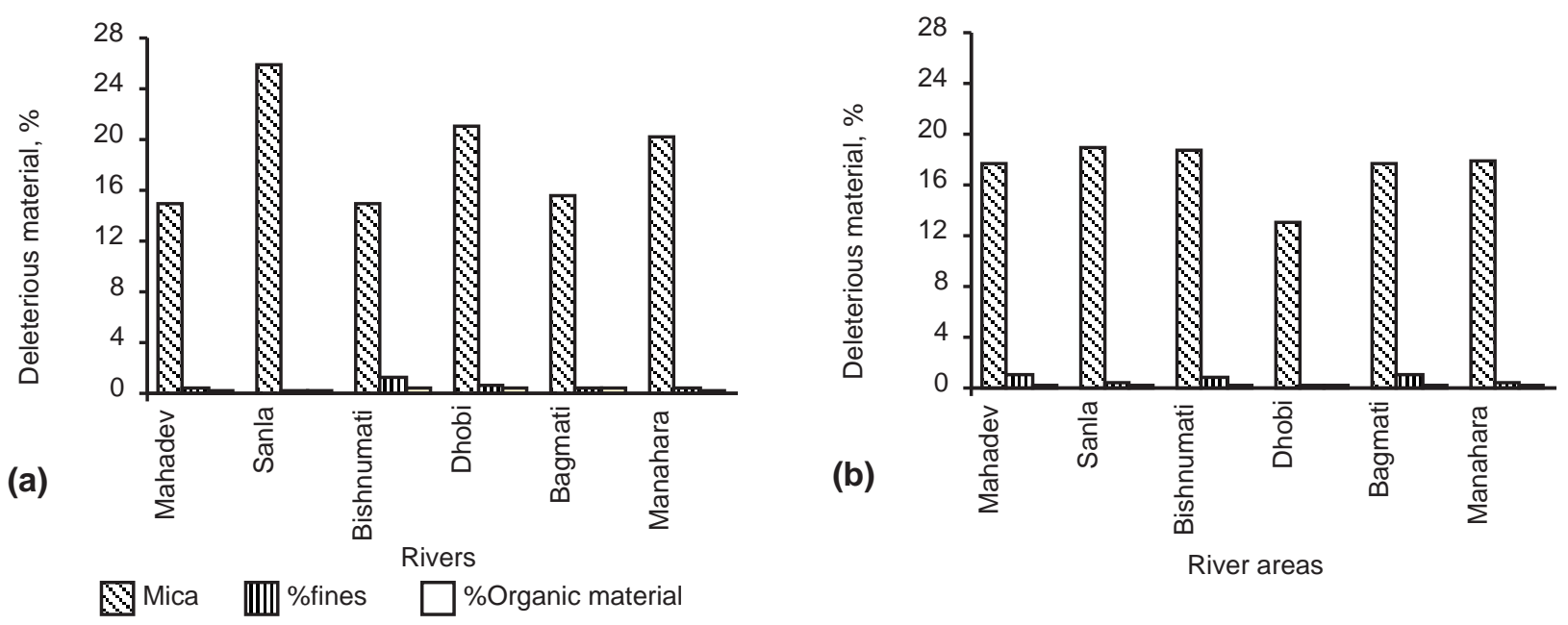

Fig. 7 Variation of deleterious materials in (a) river and (b) terrace sands

\section{ECONOMIC VALUE AND MARKET POTENTIAL}

The high demand of sand, as raw materials for construction purpose (in concrete pavement, building, foundation, etc.), leads to economic value of sand in the Kathmandu Valley. The cost of $2.8 \mathrm{~m}^{3}$ (1 truck) of sand is Rs. 1000 to Rs. 2200. Sands available in the market can be divided into three categories:

(1) Sand that costs Rs. 1000-1200 per truck. It is extracted by landowner or contractor from small terraces illegally. Contractors sell sand without processing.

(2) Sand that costs Rs. 1600-2000, and comes from riverbed and is washed and sieved during mining and therefore is better in terms of fines and sorting than the terrace sands.

(3) Sand that costs Rs. 2200-2800, which is legal including labor charge, royalty of District Development Committee, Government tax and transportation charge.

Government issues license to the contractor, who will be the responsible in dealing with excavation, renewing license, paying workers and paying royalty to the government. Contractor may also be the landowner of sand deposit. The labor charge was Rs. 100 per labor per day ( 7 a.m. to 6 p. m.). The royalty to be paid to District Development Committee (Nepal Government) was Rs. 160 per truck. Sometimes, contractors should pay local taxes between Rs. 15 and Rs. 50 for local development. In case of illegal mining, contractors should pay about Rs. 300 per truck to landowners. In the village area, local people collect sands from riverbed and they sell directly to truck drivers. The dwellers sold sand at the rate of Rs. 10 per sack. The truck drivers should pay the royalty of Rs. 160 per truck. They sometimes sell sand to the processing company, otherwise they directly sell in the market as shown in Fig. 8.

\section{SOCIO-ECONOMIC ASPECT}

Due to high demand of sand in the market, many people are involved with sand excavation. Excavation has been undergoing so haphazardly that it is out of control to the District Development Committee. Several illegal quarries have been undergoing both in rivers and terraces. Although, such mining activities in long term affect human and environment, for the time being, such activities are proving good opportunity to many people for hand to mouth. Some mining companies have also evolved as small industries to highly facilitated processing companies. From the sand mining, landowner, company owner, contractor, labor and driver are getting employment opportunity. All their dependants indirectly or directly depend on mining activities.

Sand mining activities are closely associated with housing in the riverbank areas in recent time. Large terraces after being excavated for sand, are used for housing and agricultural land. Because construction of houses in the valley has increased enormously, the 


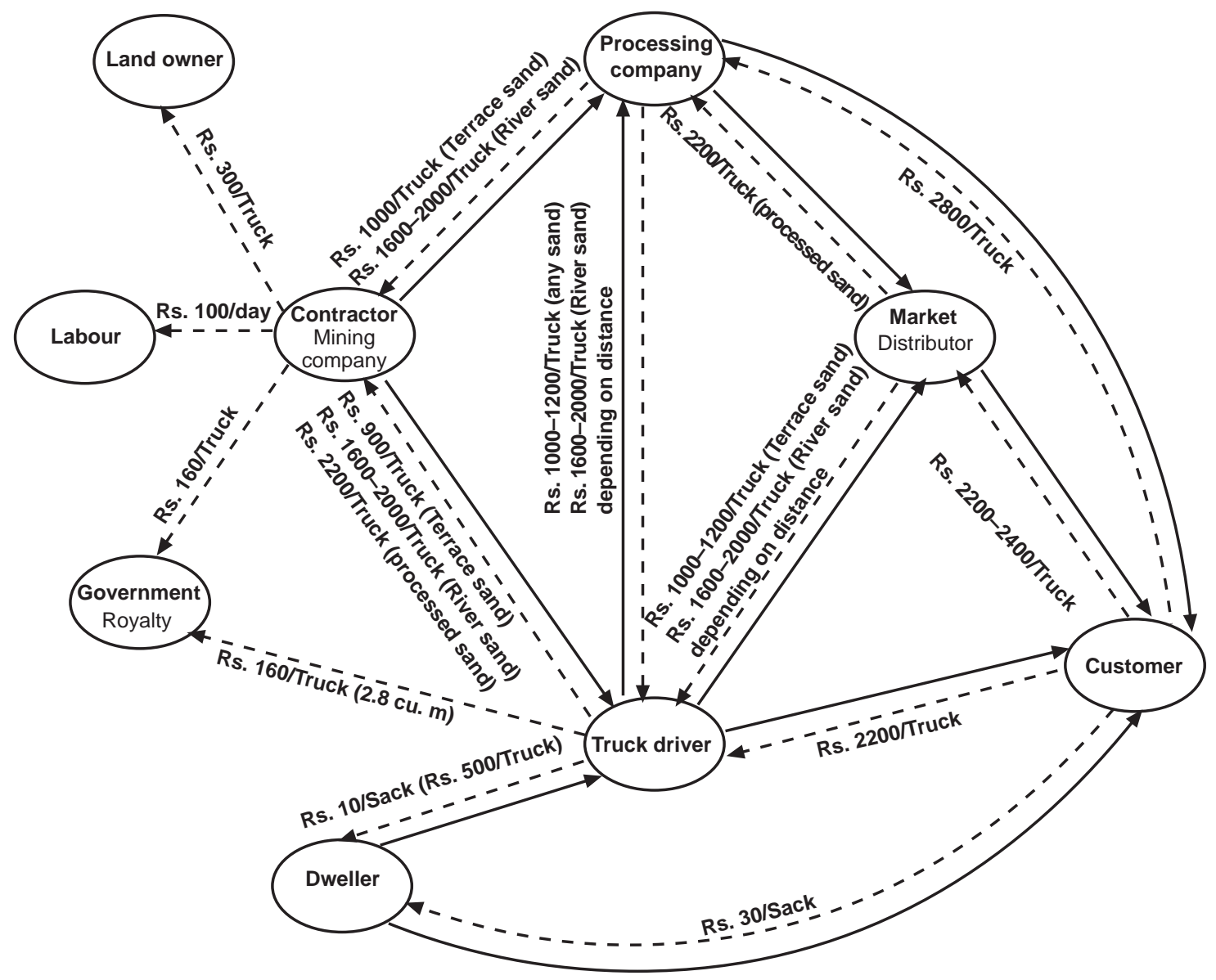

Fig. 8 Flow diagram showing distribution channel of sand from the production site to the market and consumer; dotted line shows flow of amount and solid line indicates flow of sand; one truck equals to approximately 2.8 cubic meter

housing company itself purchases terraces and excavates sand for both selling and for using by itself to build houses. Therefore, not only individual but also company and government are benefited from the sand mining. If proper methods of licensing and taxation could be established and if mine operations could be inspected, the mining would not become haphazard.

\section{ENVIRONMENTAL ASPECTS}

Environment of Kathmandu is degrading with time. One of the major causes is haphazard mining without considering environment. Riverbed excavation of sand has affected bridge, roads, cultural heritages (temples and crematories) and many houses. Exposure of foundation of bridge has been caused by excessive riverbed sand excavation. Tamrakar (2004) and Bajracharya (2006) stated that riverbed mining was one of the major causes of river degradation and accelerated streambank erosion.

Water quality of the rivers has been deteriorated because of sediment flux caused by river mining. Several aquatic lives have lost their habitats because of high turbidity of water and pollution of surface water. Excessive extraction of sand beyond the reported depth has also caused degradation of land where water impounds during monsoon. River mining is also associated with encroachment of riverbanks by sand dwellers and extensive pollution of surface water by them.

Terraces are generally located near the agricultural land and most of them are covered by vegetation. Sand excavation helps to accelerate the erosion rate of exposed slopes. Terrace mining also leads to change 
the natural drainage system that influences agricultural lands. Terrace mining obstructs some of the seepage and spring, which otherwise flow their way to mainstream. In some places, terrace mining has brought instability of slopes and danger to shelters.

Air pollution is probably the notable problem that has arisen by running of vehicles over dusty gravel roads. Vehicles running over cultivated fields for transport of sand have also destroyed many cultivable lands. Suspended particles and harmful gases come out from the vehicles adversely affect the air and health of mine workers and people of surrounding.

\section{CONCLUSIONS}

Sand mining in the Kathmandu Valley has been continuing in terraces and riverbeds. About $1865 \mathrm{~m}^{3}$ sands from river (60\% of demand) and $1238 \mathrm{~m}^{3}$ from terraces $(40 \%)$ have been excavated each day. The total of $3103 \mathrm{~m}^{3}$ of sand has been excavated each day to fulfill the demand in the Kathmandu Valley. In future this demand may increase considering 40 to $60 \%$ increase of household in the valley.

The Sanla and the Manahara Rivers are the most efficiently excavated rivers, while the Mahadev and the Manahara River areas are the most excavated terraces. About $45 \%$ of excavation were found to be illegal (40\% of river sites and 5\% of terrace sites). Mining policy and laws are not strong enough to control illegal mining and to bring miners and dwellers into the framework of taxation. The local government could not obtain benefit from the mining despite of huge loss of river environment in the valley.

The river or terrace sands do not exhibit significant difference in texture and composition, but river sands are mineralogically more matured than the terrace sands. These sands are hazardous in terms of mica content that approaches 10 to $32 \%$ and lies beyond the acceptable limit of $8 \%$. Other deleterious materials are quite low in percentage. If processing can be applied to reduce mica content at a commercial-scale, the river and terrace sands in the Kathmandu Valley will be probably the good quality sands.

\section{ACKNOWLEDGEMENTS}

Authors thank Central Department of Geology for providing lab facilities. Authors thank S. Maharjan, P.
Shrestha and U. Raghubanshi for assistance during sampling.

\section{REFERENCES}

Adhikari, B.R. and Tamrakar, N.K., 2005. Bank instability and erosion problems of Bishnumati River, Kathmandu, Nepal, Journal of Nepal Geological Society, Special Issue, V. 32,

Bajracharya, R., 2006. Study of geoenvironmental problems of the Manohara River, Kathmandu, Nepal. Unpublished M. S. Thesis submitted to Central Department of Geology, Tribhuvan University, Kathmandu, Nepal, 132p.

British Standards Institution, 1973, Specification for aggregates from natural sources for concrete (including grano-lithic): BS 882.

CBS, 2001. Population and households of Kathmandu.

Dickinson, W.R., Lawton, T.F., and Inman, K.F., 1986. Sandstone detrital modes, central Utah Foreland region: Stratigraphic record of Cretaceous-Paleogene tectonic evolution. Jour. Sed. Petrology, V. 56 (2), pp. 276-293.

DMG, 1984. Geological map of central Nepal. Department of Mines and Geology, Kathmandu, Nepal.

Fookes, P.G. and Revie, W.A., 1982. Mica in concrete-a case history from Eastern Nepal. Concrete, V. 16, No. 3, pp.12-16.

Kharel, B.D., Maharjan, S.R., Gyanwali, B.M., Shakya, R.R., Pradhananga, U.P., Jha, S.N. and Duwadi, A.K., 2002. Sand resources assignment in the Kathmandu Valley, a report submitted to Department of Mines and Geology, Kathmandu, 10p.

Kharel, B.D., Koirala, A., Neupane, D. and Chaudhari, S.N., 1992. Preliminary evaluation of the problem concerning sand extraction in the Kathmandu Valley. A report submitted to Department of Mines and Geology, 17p.

Paudel, A., Baidya, H., Khada, T., Shrestha, P., Bista, S., Kharel, P., Thapa, G., and Suwal, I.M., 1995. Sand mining in Kathmandu and its environmental implication; a case study. A report submitted to CEDA, 22p.

Sadaula, D.K., 1993. Sand in Kathmandu Valley: prospect and problem. Unpublished M.Sc. Thesis submitted to the Central Department of Geology, Tribhuvan University.

Stöcklin, J., Bhattarai, K.D., 1982. Photogeological map of part of central Nepal. Tehran Naqshah Offset Press, Iran.

Tamrakar, N.K., 2004. Disturbances and instabilities in the Bishnumati River corridor, Kathmandu basin, JUSAN, v.9, pp. Issue 16, pp. 7-18.

Yoshida, M. and Igarashi, Y., 1984. Neogene to quaternary lacustrine sediments in the Kathmandu Valley, Nepal, Journal of Nepal Geological Society, Special Issue, v. 4, pp. 73-100. 